\title{
Leptin receptor gene polymorphisms are associated with adiposity and metabolic alterations in Brazilian individuals
}

\author{
Polimorfismos no gene do receptor de leptina são associados com \\ adiposidade e alteraçōes metabólicas em indivíduos brasileiros
}

Raquel de Oliveira' , Alvaro Cerda',2, Fabiana Dalla Vecchia Genvigir', Marcelo Ferraz Sampaio ${ }^{2}$, Dikran Armaganijan 3 , Marcia Martins Silveira Bernik ${ }^{4}$, Egidio Lima Dorea ${ }^{4}$, Mario Hiroyuki Hirata' ', Hamilton Massayuki Hinuy', Rosario Dominguez Crespo Hirata'

\begin{abstract}
Objective: The aim of the study was to investigate whether adiposity and metabolic markers, such as leptin, glucose, and lipids, are influenced by leptin (LEP) and leptin receptor (LEPR) gene polymorphisms in a sample of our population. Subjects and methods: A group of 326 individuals of Caucasian-European descent, aged 30 to 80 years, 87 men and 239 women, 148 obese and 178 non-obese, was randomly selected at two clinical hospitals in the city of Sao Paulo, Brazil. All individuals declared their ethnic group as white during the initial interview. Anthropometric measurements, body mass index (BMI), and fat mass were evaluated. Blood samples were drawn for DNA extraction and measurements of leptin, soluble leptin receptor, glucose, and lipids. LEP -2548G>A and LEPR Lys109Arg (c.326A>G), Gln233Arg (c.668A>G) and Lys656Asn (c.1968G>C) polymorphisms were detected by PCR-RFLP. Results: Increased leptin and serum lipids, and LEPR Arg223Arg (GG genotype) were associated with higher risk for obesity $(p<0.05)$, while reduced risk was found in LEPR Arg109Arg (GG genotype) carriers (OR: 0.38, 95\% Cl: 0.19-0.77, $\mathrm{p}=0.007$ ). Multiple linear regression analysis showed a relationship between LEPR 223Arg, increased waist circumference, and leptinemia $(\mathrm{p}<0.05)$, while LEPR 109Arg was associated with high total cholesterol and triglycerides ( $\mathrm{p}<0.05$ ). LEPR haplotype 3 (AGG: 109Lys/233Arg/656Lys) carriers have increased risk for obesity (OR: 2.56, 95\% Cl: 1.19-5.49, $\mathrm{p}=0.017$ ). Moreover, this haplotype was associated with increased BMI, waist circumference, and leptinemia $(p<0.05)$. Conclusions: LEPR polymorphisms are associated with obesity, hyperleptinemia, and atherogenic lipid profile, suggesting their potential role for leptin resistance and cardiovascular risk. Moreover, LEPR haplotype 3 confers susceptibility to adiposity and hyperleptinemia in our population. Arq Bras Endocrinol Metab. 2013;57(9):677-84
\end{abstract}

\section{Keywords}

Leptin; leptin receptor; gene polymorphisms; adiposity; lipids

\section{RESUMO}

Objetivo: 0 estudo teve por objetivo investigar a influência de polimorfismos nos genes da leptina (LEP) e do receptor de leptina (LEPR) na adiposidade e em marcadores metabólicos, como leptina, glicose e lipídeos, em uma amostra de nossa população. Sujeitos e métodos: Um grupo de 326 indivíduos com idade de 30 a 80 anos, 87 homens e 239 mulheres, 148 obesos e 178 não obesos, e de etnia branca foi selecionado aleatoriamente em dois hospitais clínicos da cidade de São Paulo, Brasil. Medidas antropométricas, índice de massa corporal (IMC) e gordura corporal foram avaliados. Amostras de sangue foram obtidas para extração de DNA e determinações de leptina, receptor de leptina solúvel, glicose e lipídeos. Os polimorfismos LEP -2548G>A e LEPR Lys109Arg (c.326A>G), Gln233Arg (c.668A>G) e Lys656Asn (c.1968G>C) foram detectados por PCR-RFLP. Resultados: Leptina e lipídeos séricos aumentados e LEPRArg223Arg (genótipo $\mathrm{GG}$ ) foram associados com maior risco de obesidade $(p<0,05)$, enquanto foi encontrado risco reduzido de obesidade, em portadores de LEPR Arg109Arg (genótipo GG) (OR: 0,38, 95\%Cl: 0,19-0,77, p=0,007). A análise de regressão linear múltipla mostrou relação entre o alelo LEPR 223Arg e circunferência abdominal e leptinemia aumentadas $(p<0,05)$, enquanto o alelo LEPR 109Arg foi associado com aumento de colesterol total e triglicerídeos $(\mathrm{p}<0,05)$. Os portadores do haplotipo 3 do LEPR (AGG: 109Lys/233Arg/656Lys) tiveram maior risco aumentado para obesidade (OR: 2.56, 95\% Cl: 1.19-5.49, $p=0,017$ ). Além disso, esse haplótipo foi associado com IMC, circunferência abdominal e leptinemia aumentados $(p<0,05)$. Conclusões: Polimorfismos de $L E P R$ são associados com obesidade, hiperleptinemia e perfil lipídico aterogênico sugerindo seu papel potencial para a resistência à leptina e risco cardiovascular. Arq Bras Endocrinol Metab. 2013;57(9):677-84

\section{Descritores}

Leptina; receptor de leptina; polimorfismos nos genes; adiposidade; lipídeos

${ }^{1}$ School of Pharmaceutical Sciences, University of Sao Paulo (USP), Sao Paulo, SP, Brazil 2 Universidad de La Frontera, Temuco, Chile

${ }^{3}$ Dante Pazzanese Institute of Cardiology, Sao Paulo, SP, Brazil ${ }^{4}$ University Hospital, USP, SP, Brazil
Correspondence to: Rosario Dominguez Crespo Hirata Av. Prof. Lineu Prestes, 580, bloco 17 05508-900 - São Paulo, SP, Brazil rosariohirata@usp.br

Received on Jan/8/2013 Accepted on Aug/7/2013 


\section{INTRODUCTION}

$\mathrm{O}$ besity is caused by excessive fat accumulation that results from a positive balance between total energy intake and fat catabolism (1). Obesity arises from a complex interaction between genetic variance, environment, and lifestyle changes. Fat excess is an important predisposing factor for serious medical conditions such as type 2 diabetes, cardiovascular disease, stroke, cancer, psychiatric illness, and premature death (2).

Leptin, a hormone secreted mainly by the white adipose tissue, regulates food intake, body temperature and energy homeostasis through the interaction with leptin receptors (LEPR) expressed in the hypothalamus (3-5). The reduced ability of leptin to regulate appetite and weight gain is known as leptin resistance, which can lead to obesity-related phenotypes (6). Defects in leptin transport across the blood-brain barrier, in LEPR signaling and in the neural pathways involved in energy homeostasis regulation are some of the mechanisms involved in the resistance to leptin (6).

Single nucleotide polymorphisms (SNPs) in leptin $(L E P)$ and leptin receptor ( $L E P R)$ have been shown to be linked to obesity-related metabolic markers and phenotype (7-10). Studies have suggested that LEP rs7799039 $(-2548 \mathrm{G}>\mathrm{A})$ and $\mathrm{rs} 2167270(19 \mathrm{~A}>\mathrm{G})$ SNPs are associated with either variation in increased leptinemia and/or obesity susceptibility in several populations (11-14).

Common SNPs in LEPR, such as Lys109Arg (rs1137100), Gln223Arg (rs1137101), and Lys656Asn (rs8179183) have also been related with adiposity, increased BMI, weight gain, hyperleptinemia or predisposition to leptin resistance in different populations (10). The LEPR Gln223Arg was associated with adiposity and increased leptinemia in middle-aged Caucasian individuals in Canada (15). This variant was also associated with obesity and predicted a small percentage of body weight and body composition variability in a genetically homogeneous population in Greece (16). The LEPR Q223R polymorphism is also one of the factors contributing to the high prevalence of obesity in the Pacific Island populations (17). In Brazil, the LEPR Gln223Arg variant was associated with BMI increase, especially in non-smokers, in a sample population of European descent in the South region of the country (18). In addition, Gln223Arg SNP was related to BMI increase in another Brazilian sample of different genetic backgrounds and ethnic origins settled in an urban area of the Rio de Janeiro (19). LEPR Lys109Arg variant was found to be associated with obesity and preference for sweets in individuals from Osaka, Japan (20). Moreover, this polymorphism was associated with quantitative measures of adiposity (weight, BMI, and waist and hip circumferences) in children from an urban region of India (21).

We have investigated the influence of the $L E P$ and LEPR common variants on adiposity and metabolic markers, such as leptin, glucose, and lipids in a sample of obese and non-obese individuals in the city of Sao Paulo, Brazil.

\section{SUBJECTS AND METHODS}

\section{Study subjects}

A group of 326 unrelated Brazilian individuals, 148 obese and 178 non-obese, 87 men and 239 women (110 post-menopause), aged 30 to 80 years old, was randomly selected from two Clinical Hospitals (Dante Pazzanese Institute of Cardiology and the University Hospital of the Univesity of Sao Paulo). All participants declared that they were of European-Caucasian descent, and lived in the urban area of the city of Sao Paulo, in the southeast of Brazil.

All individuals were informed about the study's protocol and then agreed to participate as volunteers by signing an informed consent form. The study protocol was approved by the ethics committees of the Dante Pazzanese Institute of Cardiology (Protocol \# 3419), School of Pharmaceutical Sciences (Protocol \# 471), and University Hospital of the University of Sao Paulo (Protocol \# 812/08).

Anthropometric measurements, such as BMI, waist circumference (WC), waist-to-hip ratio (WHR), and body fat mass measured by bioimpedance were recorded for each participant. Systolic/diastolic blood pressure was measured in supine position after a 30-min rest period by a trained physician using a mercury column sphygmomanometer.

Based on World Health Organization (WHO) recommendations, subjects with $\mathrm{BMI} \geq 30 \mathrm{~kg} / \mathrm{m}^{2}$ were classified as obese and those with systolic/diastolic blood pressure over to $140 / 90 \mathrm{mmHg}$ or were under anti-hypertensive therapy were considered hypertensive. Individuals with fasting plasma glucose over $100 \mathrm{mg} / \mathrm{dL}$ were considered hyperglycemic. Current cigarette smoking was defined as a daily intake of one or more cigarettes. Alcohol consumption was considered 
when daily intake of beer, wine, and distilled spirits was $\geq 1 \mathrm{~g} /$ day. Physical activity was considered practice of sports, for example, walking, running our swimming, for at least 2 hours a week. Family history of coronary artery disease (CAD) was also recorded.

\section{Metabolic markers measurements}

A 12-h fasting blood sample was collected from each participant for serum lipids, and plasma glucose, leptin, and soluble leptin receptor (sLEPR) determinations. Glucose, triglycerides, and total cholesterol and high-density lipoprotein (HDL) cholesterol were measured by enzymatic-colorimetric assays using a Roche-Hitachi 912 automated analyzer (Hitachi, Nakakojo, Japan). Low-density lipoprotein (LDL) and very low-density lipoprotein (VLDL) cholesterol values were calculated by Fridewald's formula. Plasma leptin and sLEPR were determined by an ELISA assay (Alexis Biochemical/Vendor BioAgency, Sao Paulo, Brazil).

\section{DNA isolation and genotyping}

Genomic DNA was isolated from $1 \mathrm{~mL}$ EDTA-anticoagulated whole blood samples using the salting-out method (22). The LEP rs7799039 (-2548G>A) and LEPR rs1137100 (Lys109Arg, c.326A>G), rs1137101 (Gln223Arg, c.668A>G) and rs8179183 (Lys656Asn, c.1968G>C) SNPs were chosen based on literature reports.

LEP-2548G $>$ A variant was detected by PCR-RFLP using a previously described protocol (23). LEPR Lys109Arg, Gln223Arg and Lys656Asn SNPs were also detected by PCR-RFLP. Primers and PCR conditions are shown in supplementary table 1. PCR assays contained $50 \mathrm{ng}$ genomic DNA, $200 \mu \mathrm{mol} / \mathrm{L}$ primers (Invitrogen Corporation, CA, USA), 200 mmoles/L dNTPs (GE Healthcare, Buckinghamshire, England), and 1.0 U DNA polymerase and PCR buffer $[50 \mathrm{mmol} / \mathrm{L}$ $\mathrm{KCl}, 20 \mathrm{mmol} / \mathrm{L}\left(\mathrm{NH}_{4}\right)_{2} \mathrm{SO}_{4}, 2 \mathrm{mmol} / \mathrm{L} \mathrm{MgCl}_{4}, 75$ $\mathrm{mmol} / \mathrm{L}$ Tris-HCl(pH 9.0)] (Biotools, Madrid, Spain). The amplification was carried out in a PTC-200 Thermal Cycler (MJ Research, Watertown/MA).

PCR products from LEPR Lys109Arg, Gln223Arg and Lys656Asn assays were digested with MboII (New England, BioLabs, USA), MspI (Fermentas, Vilnius, Lithuania), and Bst U I (Fermentas, Vilnius, Lithuania) endonucleases, respectively, at $37^{\circ} \mathrm{C}$ for $4 \mathrm{~h}$. Restriction fragments were identified by $8 \%$ polyacrylamide gel electrophoresis.
The accuracy of genotyping was evaluated by performing duplicate analysis of $30 \%$ of the randomly selected samples, and no genotyping errors were detected. DNA samples with known genotypes confirmed by DNA sequencing were used as controls in PCR and RFLP assays.

\section{Statistical methods}

Chi-square test was used to compare categorical variables and the agreement of genotypes frequencies with Hardy-Weinberg equilibrium (HWE) expectations. The sample size to estimate the frequencies of polymorphis$\mathrm{ms}$ in our population was calculated considering a confidence level of $95 \%(z=1.96)$ and a 0.06 error for the estimated proportion. The minimum sample size for the study was 267 individuals. Continuous variables are presented as means $\pm \mathrm{SD}$, and the effects of the polymorphisms on metabolic markers were evaluated by $t$-test and one-way analysis of variance (ANOVA). Variables without normal distribution underwent log transformation for analysis. Multiple logistic regression analysis was performed to assess the influence of clinical variables and polymorphisms in the risk of obesity. The influence of polymorphisms in the risk for obesity was also tested using the SNPassoc software. The influence of polymorphisms on continuous variables was also evaluated by linear regression analysis adjusted by covariates. Statistical analyses were performed using the SAS Systems for Windows, version 8.02 (SAS Institute Inc., Carry, NC), assuming a significance level of $\mathrm{p}<0.05$. Haplotype frequencies and linkage disequilibrium coefficient (D') were assessed by the Expectation-Maximization (EM) algorithm using the Haploview Software. Comparison of haplotype frequencies between case and controls was performed by the chi-square test corrected for multiple tests using permutations testing. The haplo.glm function of the program Haplo.Stats (24) was used to evaluate the effect of haplotypes on the risk for obesity, and the influence of haplotypes on related continuous variables.

\section{RESULTS}

Data on anthropometric, clinical, and metabolic markers of the studied group are shown in table 1. As expected, obese individuals have higher mean age, BMI, waist circumference, waist-hip ratio and body fat mass than non-obese individuals $(\mathrm{p}<0.001)$. Hypertension, hyperglycemia, family history of $\mathrm{CAD}$, and menopause were more frequent in obese than in non-obese individuals $(\mathrm{p}<0.05)$. 
Table 1. Anthropometric, clinical, and metabolic data of obese and non-obese individuals

\begin{tabular}{|c|c|c|c|}
\hline Variables & Obese (148) & Non-obese (178) & p-value \\
\hline Age, years & $51 \pm 12$ & $45 \pm 12$ & $<0.001$ \\
\hline Women, \% & 80.4 (119) & $77.5(138)$ & 0.564 \\
\hline Menopause, \% & $42.6(63)$ & $26.4(47)$ & 0.033 \\
\hline Hypertension, \% & $50.0(74)$ & $14.0(25)$ & $<0.001$ \\
\hline Hyperglycemia, \% & $66.8(99)$ & $21.9(39)$ & $<0.001$ \\
\hline Family history of CAD, \% & $22.9(34)$ & $14.1(25)$ & 0.042 \\
\hline Cigarette smoking, \% & $39.2(58)$ & $33.7(60)$ & 0.107 \\
\hline Body mass index, $\mathrm{kg} / \mathrm{m}^{2}$ & $34.8 \pm 4.8$ & $23.5 \pm 3.4$ & $<0.001$ \\
\hline Waist circumference, $\mathrm{cm}$ & $104 \pm 16$ & $86 \pm 11$ & $<0.001$ \\
\hline Waist-hip ratio & $0.90 \pm 0.08$ & $0.85 \pm 0.09$ & $<0.001$ \\
\hline Body fat mass, $\%$ & $39.9 \pm 4.5$ & $25.3 \pm 5.2$ & $<0.001$ \\
\hline Leptin, ng/mL ${ }^{\mathrm{a}}$ & $35.0 \pm 26.2$ & $13.3 \pm 11.7$ & $<0.001$ \\
\hline sLEPR, ng/mL & $23.2 \pm 11.2$ & $30.6 \pm 23.2$ & $<0.001$ \\
\hline Glucose, mg/dL & $111 \pm 34$ & $93 \pm 16$ & $<0.001$ \\
\hline \multicolumn{4}{|l|}{ Lipid profile, mg/dL } \\
\hline Total cholesterola & $217 \pm 34$ & $170 \pm 39$ & $<0.001$ \\
\hline HDL cholesterol & $51 \pm 11$ & $58 \pm 15$ & $<0.001$ \\
\hline LDL cholesterol & $134 \pm 38$ & $116 \pm 32$ & $<0.001$ \\
\hline VLDL cholesterol & $31 \pm 12$ & $24 \pm 12$ & $<0.001$ \\
\hline Triglycerides & $158 \pm 66$ & $108 \pm 62$ & $<0.001$ \\
\hline Apolipoprotein Al & $131 \pm 29$ & $140 \pm 32$ & 0.363 \\
\hline Apolipoprotein B & $107 \pm 29$ & $91 \pm 25$ & $<0.001$ \\
\hline
\end{tabular}

Number of individuals is in parenthesis. Results are presented as mean \pm SD and compared by $t$-test and Mann-Whitney test. Categorical variables were compared by chi-square. HDL: high-density

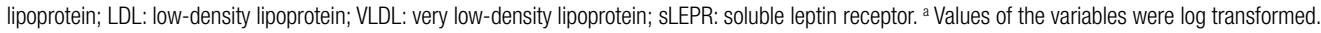

Supplementary Table 1. Primer sequences and PCR conditions for LEPR polymorphisms

\begin{tabular}{|c|c|c|c|c|}
\hline Polymorphism & Primer sequences & Number of cycles & Annealing temperature & Amplicon size \\
\hline Lys109Arg (rs1137100) & $\begin{array}{c}\text { 5'-TGCAGACAACATTGAAGGGA-3', } \\
\text { 5'-CATACAGGTATCAAAGAATTAAAAAC-3' }\end{array}$ & 35 & $57^{\circ} \mathrm{C}$ & $128 \mathrm{bp}$ \\
\hline Gln223Arg (rs1137101) & $\begin{array}{c}\text { 5'-ATGTTGTGAATGTCTTGTGCCGG-3' } \\
\text { 5'-CCATATTTATGGGCTGAACTGACATTAG-3 }\end{array}$ & 35 & $62^{\circ} \mathrm{C}$ & $128 \mathrm{bp}$ \\
\hline Lys656Asn (rs8179183) & $\begin{array}{l}\text { 5'-ACAACTTGTCATTTGCAGTTCCTA-3' } \\
\text { 5'-CCAAAGTAAAGTGACATTTTCGC-3' }\end{array}$ & 35 & $56^{\circ} \mathrm{C}$ & $121 \mathrm{bp}$ \\
\hline
\end{tabular}

Plasma leptin and glucose, serum lipids (total, LDL, and VLDL cholesterol, and triglycerides) and apoB were higher in obese individuals $(\mathrm{p}<0.001)$, while plasma sLEPR and serum HDL cholesterol were higher in non-obese individuals $(\mathrm{p}<0.001)$.

Genotype distributions of $L E P$ and $L E P R$ variants were expected from the HWE in both the obese and non-obese group $(\mathrm{p}>0.05)$. Genotype and allele frequencies of $L E P-2548 \mathrm{G}>\mathrm{A}$, LEPR Gln223Arg (c.668A $>\mathrm{G}$ ) and LEPR Lys656Asn (c.1968G >C) polymorphisms were similar in the obese and non-obese group (Table 2). LEPR 109Arg (c.326G) allele, as well as GG genotype, was less frequent in obese $(37.8 \%)$ than in non-obese individuals $(47.2 \%, \mathrm{p}=0.020)$.

Multiple logistic regression analysis using clinically relevant covariates (age, gender, cigarette smoking and CAD) was performed (Table 3). After adjustment, an increased risk for obesity was observed for each unit increment $(\mathrm{mg} / \mathrm{dL})$ of total cholesterol (1\%), LDL cholesterol (1\%), VLDL cholesterol (4\%) and triglycerides (1\%). Similarly, each unit increment of glucose and leptin increased the risk for obesity $(5 \%$ and $8 \%$, respectively). Conversely, HDL cholesterol was related to a lower risk for obesity (OR: 0.95, 95\%CI: 0.93-0.97). 
Table 2. Frequencies of $L E P$ and $L E P R$ polymorphisms in obese and nonobese individuals

\begin{tabular}{|c|c|c|c|c|}
\hline Polymorphisms & $\begin{array}{c}\text { Genotypes/ } \\
\text { Allele/ } \\
\text { haplotypes }\end{array}$ & $\begin{array}{c}\text { Obese } \\
\text { (148) }\end{array}$ & $\begin{array}{c}\text { Non-obese } \\
\text { (178) }\end{array}$ & p-value \\
\hline \multirow[t]{4}{*}{$L E P-2548 G>A$} & GG & $12.2 \%(18)$ & $19.7 \%(35)$ & \\
\hline & GA & $50.0 \%(74)$ & $45.5 \%(81)$ & 0.182 \\
\hline & $A A$ & $37.8 \%(56)$ & $34.8 \%(62)$ & \\
\hline & A allele & $37.2 \%$ & $42.4 \%$ & 0.200 \\
\hline LEPR Lys109Arg & AA & $35.8 \%(53)$ & $31.5 \%(56)$ & \\
\hline \multirow[t]{3}{*}{$(c .326 A>G)$} & $A G$ & $52.7 \%(78)$ & $42.7 \%(76)$ & 0.004 \\
\hline & $\mathrm{GG}$ & $11.5 \%(17)$ & $25.8 \%(46)$ & \\
\hline & G allele & $37.8 \%$ & $47.2 \%$ & 0.020 \\
\hline LEPR GIn223Arg & $\mathrm{AA}$ & $41.9 \%(62)$ & $47.2 \%(84)$ & \\
\hline \multirow[t]{3}{*}{ (c.668A>G) } & $A G$ & $41.2 \%(61)$ & $43.8 \%(78)$ & 0.098 \\
\hline & GG & $16.9 \%(25)$ & $9.0 \%(16)$ & \\
\hline & G allele & $37.5 \%$ & $30.9 \%$ & 0.091 \\
\hline LEPR Lys656Asn & $G G$ & $43.9 \%(65)$ & $46.1 \%(82)$ & \\
\hline \multirow[t]{3}{*}{ (c.1968G>C) } & GC & $46.6 \%(69)$ & $48.9 \%(87)$ & 0.304 \\
\hline & CC & $9.5 \%(14)$ & $5.0 \%(9)$ & \\
\hline & $\mathrm{C}$ allele & $30.7 \%$ & $23.5 \%$ & 0.321 \\
\hline \multicolumn{5}{|l|}{ LEPR haplotypes } \\
\hline 1 & AAG & $23.3 \%$ & $25.3 \%$ & 0.999 \\
\hline 2 & AAC & $15.5 \%$ & $15.4 \%$ & 0.972 \\
\hline 3 & AGG & $21.3 \%$ & $10.9 \%$ & 0.029 \\
\hline 4 & AGC & $2.1 \%$ & $1.2 \%$ & 0.857 \\
\hline 5 & GAG & $14.0 \%$ & $19.6 \%$ & 0.136 \\
\hline 6 & GAC & $9.7 \%$ & $8.8 \%$ & 1.000 \\
\hline 7 & GGG & $8.6 \%$ & $14.7 \%$ & 0.717 \\
\hline 8 & GGC & $5.5 \%$ & $4.1 \%$ & 0.988 \\
\hline
\end{tabular}

Comparison of frequencies between case and controls was performed by chi-square test. For haplotype analysis, the test was corrected for multiple tested using permutations testing using Haploview software.

Assessment of the LEPR variants, after adjustment for these covariates, showed that individuals carrying the c.326GG genotype have lower risk for obesity (OR: $0.38,95 \% \mathrm{CI}: 0.19-0.77, \mathrm{p}=0.007)$ than c.326AA+AG genotype carriers (Table 3). On the other hand, the LEPR c.668GG genotype was associated with increased risk for obesity (OR: 2.14, 95\%CI: 1.01-4.52, p = 0.047). LEP -2548G $>\mathrm{A}$ and $L E P R$ c.1968G $>\mathrm{C}$ were not related to obesity in this sample. These results were confirmed when we used the SNPassoc software analysis.

We also evaluated the influence of polymorphisms on anthropometric and biochemical variables related to obesity. Multiple linear regression analysis demonstrated that the LEPR 109Arg (c.326G) allele contributed with 0.027 to the increase in total cholesterol, and with 0.049 to the increase in triglyceride log transformed concentrations. Moreover LEPR 233Arg (c.668G) al-
Table 3. Multiple logistic regression analysis of variables associated with obesity

\begin{tabular}{|c|c|c|c|c|}
\hline Independent variables & & Odds ratio & $95 \% \mathrm{CI}$ & p-value \\
\hline Leptin & & 1.08 & $1.06-1.10$ & $<0.001$ \\
\hline SLEPR & & 1.00 & $0.98-1.01$ & 0.742 \\
\hline Glucose & & 1.05 & $1.03-1.08$ & $<0.001$ \\
\hline Total cholesterol & & 1.01 & $1.00-1.01$ & 0.004 \\
\hline HDL cholesterol & & 0.95 & $0.93-0.97$ & $<0.001$ \\
\hline LDL cholesterol & & 1.01 & $1.01-1.02$ & 0.001 \\
\hline VLDL cholesterol & & 1.04 & $1.02-1.06$ & $<0.001$ \\
\hline Triglycerides & & 1.01 & $1.01-1.02$ & $<0.001$ \\
\hline ApoB & & 1.02 & $1.01-1.03$ & $<0.001$ \\
\hline ApoAl & & 1.00 & $0.99-1.01$ & 0.847 \\
\hline \multicolumn{5}{|l|}{ Polymorphisms ${ }^{\mathrm{a}}$} \\
\hline \multirow[t]{3}{*}{$L E P-2548 G>A$} & GG (ref) & 1.00 & -- & -- \\
\hline & GA & 0.97 & $0.58-1.60$ & 0.891 \\
\hline & $\mathrm{AA}$ & 0.56 & $0.27-1.15$ & 0.113 \\
\hline LEPR Lys109Arg & AA (ref) & 1.00 & -- & -- \\
\hline \multirow[t]{2}{*}{$(\mathrm{c} .326 \mathrm{~A}>\mathrm{G})$} & $A G$ & 0.85 & $0.50-1.45$ & 0.549 \\
\hline & $G G$ & 0.38 & $0.19-0.77$ & 0.007 \\
\hline LEPR Gln223Arg & AA (ref) & 1.00 & -- & -- \\
\hline \multirow[t]{2}{*}{$(c .668 \mathrm{~A}>\mathrm{G})$} & $A G$ & 0.85 & $0.51-1.40$ & 0.513 \\
\hline & $G G$ & 2.14 & $1.01-4.52$ & 0.047 \\
\hline LEPR Lys656Asn & GG (ref) & 1.00 & -- & -- \\
\hline \multirow[t]{2}{*}{ (c.1968G>C) } & $\mathrm{GC}$ & 0.96 & $0.59-1.55$ & 0.870 \\
\hline & $\mathrm{CC}$ & 1.78 & $0.69-4.59$ & 0.234 \\
\hline
\end{tabular}

Age, gender, cigarette smoking and CAD were selected as covariates. ApoAl: apolipoprotein Al; ApoB: apolipoprotein B; HDL: high-density lipoprotein; LDL: low-density lipoprotein; VLDL: very low-density lipoprotein; SLEPR: soluble leptin receptor. ${ }^{a}$ Data were also analyzed and confirmed by SNPassoc software.

lele (c.668AG/GG genotypes) contributed with 4.86 $\mathrm{cm}$ to the increase in waist circumference, and with $0.136 \mathrm{ng} / \mathrm{mL}$ to the increase in plasma leptin $(\mathrm{p}<$ 0.05 ) (Table 4). Altogether, this allele and the selected covariates (age, gender, cigarette smoking, CAD, and obesity) accounted for $55 \%$ and $41 \%$ of the variability in waist circumference and leptinemia, respectively.

The involvement of LEPR haplotypes in the susceptibility to obesity was also evaluated in this study. As shown in table 2 , the haplotype 3 (AGG) comprised by LEPR 109Lys (c.326A), LEPR 223Arg (c.668G) and LEPR 656Lys (c.1968G) was more frequent in the obese $(21.3 \%)$ than in the non-obese group $(10.9 \%, \mathrm{p}=$ 0.029 ). Analysis using haplo.glm function from Haplo. Stats showed that the presence of at least one copy of this haplotype increased the risk for obesity even when adjusted by age (OR: 2.56; 95\%IC: 1.19-5.49, p = 0.017) (Table 5 ). Moreover, haplotype 3 contributed with a 4.32 $\mathrm{kg} / \mathrm{cm}^{2}$ increase in BMI, $9.45 \mathrm{~cm}$ in waist circumference, and $7.90 \mathrm{ng} / \mathrm{mL}$ in leptinemia $(\mathrm{p}<0.05$, Table 5$)$. 
Table 4. Multiple linear regression analysis: influence of $L E P$ and $L E P R$ polymorphisms on variables associated with obesity

\begin{tabular}{|c|c|c|c|c|c|c|c|c|c|}
\hline \multirow{2}{*}{ Variables } & \multicolumn{2}{|c|}{ LEP $-2548 G>A$} & \multicolumn{2}{|c|}{$\begin{array}{l}\text { LEPR Lys109Arg } \\
\text { (c.326A>G) }\end{array}$} & \multicolumn{2}{|c|}{$\begin{array}{l}\text { LEPR GIn233Arg } \\
\text { (c.668A>G) }\end{array}$} & \multicolumn{2}{|c|}{$\begin{array}{l}\text { LEPR Lys656Asn } \\
\text { (c.1968G>C) }\end{array}$} & \multirow[t]{2}{*}{$\mathbf{R}^{2 \#}$} \\
\hline & B (SE) & p-value & B (SE) & p-value & B (SE) & p-value & B (SE) & p-value & \\
\hline Waist circumference & $0.36(1.24)$ & 0.772 & $1.78(1.29)$ & 0.168 & $4.86(1.22)$ & $<0.001$ & $-1.75(1.21)$ & 0.150 & $55 \%$ \\
\hline Leptin* & $-0.032(0.041)$ & 0.433 & $-0.054(0.043)$ & 0.212 & $0.136(0.041)$ & 0.001 & $-0.021(0.041)$ & 0.601 & $41 \%$ \\
\hline Total cholesterol ${ }^{\star}$ & 0.008 (0.009) & 0.428 & $0.027(0.01)$ & 0.009 & $-0.002(0.01)$ & 0.862 & $0.002(0.01)$ & 0.864 & $11 \%$ \\
\hline Triglycerides* & $-0.007(0.022)$ & 0.739 & $0.049(0.02)$ & 0.036 & $0.025(0.022)$ & 0.261 & $-0.017(0.02)$ & 0.429 & $20 \%$ \\
\hline
\end{tabular}

Variables were adjusted for covariates age, gender, cigarette smoking, CAD and obesity. Polymorphisms were introduced as dummy variables for absence or presence of the rare allele. * Dependent variables were Log-transformed to achieve normality; " Coefficient of determination for all the four polymorphisms in the model.

Table 5. Relationship of LEPR haplotypes and variables associated with obesity

\begin{tabular}{lccccccccc}
\hline \multirow{2}{*}{ Variables } & \multicolumn{3}{c}{ Obesity } & \multicolumn{3}{c}{ Body mass index } & \multicolumn{2}{c}{ Waist circumference } & \multicolumn{2}{c}{ Leptin } \\
\cline { 2 - 9 } & $\mathbf{B}$ (SE) & OR (95\%CI) & p-value & B (SE) & p-value & B (SE) & p-value & B (SE) & p-value \\
\hline Haplotype 2 & $0.34(0.38)$ & $1.41(0.67-2.96)$ & 0.365 & $0.59(0.99)$ & 0.553 & $1.22(2.28)$ & 0.594 & $2.40(3.21)$ & 0.454 \\
Haplotype 3 & $0.94(0.39)$ & $2.56(1.19-5.49)$ & 0.017 & $4.32(0.96)$ & $<0.001$ & $9.45(2.18)$ & $<0.001$ & $7.90(3.17)$ & 0.013 \\
Haplotype 4 & $0.05(1.13)$ & $1.05(0.11-9.62)$ & 0.967 & $1.49(3.08)$ & 0.629 & $3.94(7.21)$ & 0.586 & $3.48(8.98)$ & 0.699 \\
Haplotype 5 & $-0.02(0.34)$ & $0.98(0.52-1.99)$ & 0.943 & $0.84(0.88)$ & 0.340 & $2.26(2.01)$ & 0.261 & $-0.71(2.92)$ & 0.808 \\
Haplotype 6 & $0.02(0.42)$ & $1.02(0.45-2.32$ & 0.968 & $0.60(1.12)$ & 0.593 & $3.36(2.60)$ & 0.199 & $-1.81(3.72)$ & 0.627 \\
Haplotype 7 & $-0.72(0.44)$ & $0.49(0.21-1.15)$ & 0.101 & $0.38(1.03)$ & 0.712 & $1.57(2.45)$ & 0.521 & $-1.66(3.52)$ & 0.638 \\
Haplotype 8 & $0.72(0.80)$ & $2.05(0.43-9.85)$ & 0.366 & $2.79(1.74)$ & 0.112 & $4.03(3.83)$ & 0.293 & $4.70(5.39)$ & 0.384 \\
\hline
\end{tabular}

Analysis was carried out by Haplo.Stats using haplotype 1 as reference. Variables were adjusted for the covariate age. Odds Ratio (OR) and $95 \%$ confidence interval (95\%Cl) were calculated using the antilog function (ex) from regression coefficients (B). LEPR genotypes were included together and B coefficients for haplotypes are calculated by the haplo.glm function for each model (Obesity, BMI, WC and leptin).

\section{DISCUSSION}

In this sample, obesity was associated with hypertension, hyperglycemia and an atherogenic lipid profile, suggesting that obese individuals have increased susceptibility to metabolic dysfunction and atherosclerosis, as previously proposed (25).

Hyperleptinemia and reduced sLEPR found in obese individuals indicate leptin resistance status, which is probably caused by disruption of the negative feedback loop, a classical mechanism of hormone resistance (26). Leptin resistance has been suggested to produce metabolic and inflammatory injury in several tissues and organs, including the liver, pancreas and heart. Therefore, it may increase the risk for obesity-related cardiovascular disease (27).

The gene candidate approach revealed that $L E P R$ Arg223Arg (c.668GG) increased the susceptibility to adiposity in our sample, as demonstrated by the positive relationship of LEPR 223Arg allele with increased waist circumference and leptinemia. The effect of this variant was even greater when it was combined with the non-protective LEPR 109Lys (c.326A) allele, as shown by haplotype 3 .
A relationship between the LEPR Gln223Arg variant and increased BMI was previously reported in a sample of Brazilian subjects (150 lean and 200 obese) of different genetic backgrounds and ethnic origins (European-Caucasians, mulattoes, and autochthonous Amerindians) from the urban area of the city of Rio de Janeiro. Moreover, the combination between LEPR Gln223Arg and LEP $-2548 \mathrm{G}>\mathrm{A}$ polymorphisms was related to a $58 \%$ increase in obesity risk (19). More recently, an interaction between $L E P R$ Gln223Arg and $A D R B 2$ Argl6Gly variants was associated with overweight/obesity in Brazilian individuals, highlighting the relevance of multilocus effects in the molecular basis of the obesity (28).

Data analysis from two large community-based cohort studies in North America that analyzed polymorphisms in eight obesity-related genes also demonstrated significant association between LEPR Gln223Arg variant and BMI, and change in BMI over time (29). LEPR Gln223Arg polymorphism was also found to be related to increased BMI, leptin, and insulin in diabetic individuals in India (30), as well as to hyperleptinemia after adjusting for BMI in a Micronesian population (31). 
A genome-wide association study has suggested a role of LEPR Lys109Arg and Gln223Arg polymorphis$\mathrm{ms}$ in modulating plasma levels of the soluble leptin receptor (32). However, we did not found an effect of $L E P$ and $L E P R$ variants on sLEPR, probably due to the limited sample size, influence of a number of covariates, or even to ethnic complexity.

Taking altogether, these results are suggestive of a potential role of LEPR Gln223Arg on leptin and insulin resistance and other metabolic alterations that predispose to adiposity in different populations. However, no effects were detected on body weight, composition, or energy expenditure of $129 \mathrm{P} 3 / \mathrm{J}$ mice expressing this variant and fed fat diets up to seven months (33). In vitro experiments also demonstrated that Gln223Arg did not affect activation of STAT3, which reflects leptin signaling, in 293 transfected cells treated with various doses of leptin (33). Therefore, the metabolic effects associated with this variant in humans may result from its interaction with other genetic, epigenetic or environmental factors, as previously suggested (34). As for genetic interactions, it is noteworthy that the combination of 109Lys and 223Arg alleles in LEPR (haplotype 3 ) was more strongly associated with adiposity and hyperleptinemia in our study. Nevertheless, this result may be influenced by the limited sample size.

Interestingly, LEPR Lys109Arg (c.A326G) variant was associated with increase in total cholesterol and triglycerides, suggesting its contribution to the development of a more atherogenic lipid profile in obese individuals. This result corroborates the findings of the OPERA (Oulu Project Elucidating Risk of Atherosclerosis) study, which reported an increase in total cholesterol in Argl09Arg carriers, when analysis was adjusted for sex and age (35). The authors suggested that this and other LEPR polymorphisms are independently associated with early atherosclerosis and some of its risk factors.

In conclusion, the LEPR Lys 109Arg and Gln223Arg variants are associated with obesity, hyperleptinemia, and an atherogenic lipid profile. Moreover, LEPR haplotype 3 confers susceptibility to adiposity and insulin resistance in our population.

Acknowledgements: this study was supported by a grant from $\mathrm{Fa}$ pesp (Protocol \# 2009/10069-2). We would like to thank Tamiris I. Moraes and Rebecca Kiyokawa for their technical support. R. Oliveira and F. D. V. Genvigir were recipients of fellowship from Fapesp, Brazil. A. Cerda was recipient of a fellowship from CONICYT, Chile. M. H. Hirata and R. D. C. Hirata are recipients of fellowship from CNPq, Brazil.
Disclosure: no potential conflict of interest relevant to this article was reported.

\section{REFERENCES}

1. Bray GA. Obesity:The disease. J Med Chem. 2006;49:4001-7.

2. Nguyen DM, El-Serag HB. The epidemiology of obesity. Gastroenterol Clin North Am. 2010;39:1-7.

3. Considine RV. Human leptin: an adipocyte hormone with weightregulatory and endocrine functions. Semin Vasc Med. 2005;5:15-24.

4. de Luis DA, Perez Castrillón JL, Dueñas A. Leptin and obesity. Minerva Med. 2009;100:229-36.

5. Mantzoros CS, Magkos F, Brinkoetter M, SienkiewiczE, DardenoTA, Kim SY, et al. Leptin in human physiology and pathophysiology. Am J Physiol Endocrinol Metab. 2011;301:E567-84.

6. Wauman J, Tavernier J. Leptin receptor signaling: pathways to leptin resistance. Front Biosci. 2011;17:2771-93.

7. Rankinen T, Zuberi A, Chagnon YC, Weisnagel SJ, Argyropoulos G, Walts B, et al. The human obesity gene map: the 2005 update. Obesity (Silver Spring). 2006;14:529-644.

8. Martinez-Hernandez A, Enriquez L, Moreno-Moreno MJ, Marti A. Genetics of obesity. Public Health Nutr. 2007;10:1138-44.

9. Herrera BM, Lindgren CM. The genetics of obesity. Curr Diab Rep. 2010;10:498-505.

10. Ramachandrappa S, Farooqi IS. Genetic approaches to understanding human obesity. J Clin Invest. 2011;121:2080-6.

11. Yiannakouris N, Melistas L, Yannakoulia M, Mungal K, Mantzoros $\mathrm{CS}$. The-2548G/A polymorphism in the human leptin gene promoter region is associated with plasma free leptin levels; interaction with adiposity and gender in healthy subjects. Hormones (Athens). 2003;2:229-36.

12. Jiang $Y$, Wilk JB, Borecki I, Williamson $S$, DeStefano AL, Xu G, et al. Common variants in the $5^{\prime}$ region of the leptin gene are associated with body mass index in men from the National Heart, Lung, and Blood Institute Family Heart Study. Am J Hum Genet. 2004;75:220-30.

13. Hinuy HM, Hirata MH, Sampaio MF, Armaganijan D, Arazi SS, Salazar LA, et al. Relationship between variants of the leptin gene and obesity and metabolic biomarkers in Brazilian individuals. Arq Bras Endocrinol Metabol. 2010;54:282-8.

14. Yu Z, Han S, Cao X, Zhu C, Wang X, Guo X. Genetic polymorphisms in adipokine genes and the risk of obesity: a systematic review and meta-analysis. Obesity (Silver Spring). 2012;20:396-406.

15. Chagnon YC, Wilmore JH, Borecki IB, Gagnon J, Pérusse L, Chagnon $\mathrm{M}$, et al. Associations between the leptin receptor gene and adiposity in middle-aged Caucasian males from the HERITAGE family study. J Clin Endocrinol Metab. 2000;85:29-34.

16. Yiannakouris N, Yannakoulia M, Melistas L, Chan JL, Klimis-Zacas D, Mantzoros CS. The Q223R polymorphism of the leptin receptor gene is significantly associated with obesity and predicts a small percentage of body weight and body composition variability. $J$ Clin Endocrinol Metab. 2001;86:4434-9.

17. FurusawaT, Naka I,YamauchiT, Natsuhara K, Kimura R, Nakazawa $\mathrm{M}$, et al. The Q223R polymorphism in LEPR is associated with obesity in Pacific Islanders. Hum Genet. 2010;127:287-94.

18. Mattevi VS, Zembrzuski VM, Hutz MH. Association analysis of genes involved in the leptin-signaling pathway with obesity in Brazil. Int J Obes Relat Metab Disord. 2002;26:1179-85.

19. Duarte SF, Francischetti EA, Genelhu VA, Cabello PH, Pimentel MM. LEPR p.Q223R, beta3-AR p.W64R and LEP c.-2548G>A gene variants in obese Brazilian subjects. Genet Mol Res. 2007;6:1035-43. 
20. Mizuta E, Kokubo Y, Yamanaka I, Miyamoto $Y$, Okayama A, Yoshimasa $Y$, et al. Leptin gene and leptin receptor gene polymorphisms are associated with sweet preference and obesity. Hypertens Res. 2008;31:1069-77.

21. Tabassum R, Mahendran Y, Dwivedi OP, Chauhan G, Ghosh S, Marwaha RK, et al. Common variants of IL6, LEPR, and PBEF1 are associated with obesity in Indian children. Diabetes. 2012;61:626-31.

22. Salazar LA, Hirata MH, Cavalli SA, Machado MO, Hirata RD. Optimized procedure for DNA isolation from fresh and cryopreserved clotted human blood useful in clinical molecular testing. Clin Chem. 1998;44:1748-50.

23. Hinuy $\mathrm{HM}$, Hirata $\mathrm{MH}$, Forti $\mathrm{N}$, Diament J, Sampaio MF, Armaganijan D, et al. Leptin G-2548A promoter polymorphism is associated with increased plasma leptin and BMI in Brazilian women. Arq Bras Endocrinol Metabol. 2008;52:611-6.

24. Schaid DJ, Rowland CM, Tines DE, Jacobson RM, Poland GA. Score tests for association between traits and haplotypes when linkage phase is ambiguous. Am J Hum Genet. 2002;70:425-34.

25. Cornier MA, Dabelea D, HernandezTL, Lindstrom RC, Steig AJ, Stob NR, et al. The metabolic syndrome. Endocr Rev. 2008;29:777-822.

26. Knight ZA, Hannan KS, Greenberg ML, Friedman JM. Hyperleptinemia is required for the development of leptin resistance PLoS One. 2010;5:e11376.

27. Martin SS, Qasim A, Reilly MP. Leptin resistance: a possible interface of inflammation and metabolism in obesity-related cardiovascular disease. J Am Coll Cardiol. 2008;52:1201-10.

28. Angeli CB, Kimura L, Auricchio MT, Vicente JP, Mattevi VS, Zembrzuski VM, et al. Multilocus analyses of seven candidate genes suggest interacting pathways for obesity-related traits in Brazilian populations. Obesity (Silver Spring). 2011;19:1244-51.

29. Gallicchio L, Chang HH, Christo DK, Thuita L, Huang HY, Strickland $\mathrm{P}$, et al. Single nucleotide polymorphisms in obesity-related genes and all-cause and cause-specific mortality: a prospective cohort study. BMC Med Genet. 2009;10:103.

30. Murugesan D, Arunachalam T, Ramamurthy V, Subramanian $\mathrm{S}$. Association of polymorphisms in leptin receptor gene with obesity and type 2 diabetes in the local population of Coimbatore. Indian J Hum Genet. 2010;16:72-7.

31. FurusawaT, Naka I, YamauchiT, Natsuhara K, Kimura R, Nakazawa $M$, et al.The serum leptin level and body mass index in Melanesian and Micronesian Solomon Islanders: focus on genetic factors and urbanization. Am J Hum Biol. 2011;23:435-44.

32. Sun Q, Cornelis MC, Kraft P, Qi L, van Dam RM, Girman CJ, et al. Genome-wide association study identifies polymorphisms in LEPR as determinants of plasma soluble leptin receptor levels. Hum Mol Genet. 2010;19:1846-55.

33. Stratigopoulos G, LeDuc CA, Matsuoka N, Gutman R, Rausch $\mathrm{R}$, Robertson SA, et al. Functional consequences of the human leptin receptor (LEPR) Q223R transversion. Obesity (Silver Spring). 2009;17:126-35.

34. Drong AW, Lindgren CM, McCarthy MI. The genetic and epigenetic basis of type 2 diabetes and obesity. Clin Pharmacol Ther. 2012;92:707-15.

35. Saukko M, Kesäniemi YA, Ukkola O. Leptin receptor Lys109Arg and GIn223Arg polymorphisms are associated with early atherosclerosis. Metab Syndr Relat Disord. 2010;8:425-30. 